\title{
New subtype of familial achondrogenesis type IA (Houston-Harris)
}

\author{
Nuevo subtipo de acondrogénesis familiar tipo IA (Houston-Harris)
}

\begin{abstract}
Sergio Alberto Ramírez-García1, Diana García-Cruz²*, Iván Cervantes-Aragón², Wadih Emilio Bitar-Alatorre ${ }^{3}$, Ingrid Patricia Dávalos-Rodríguez ${ }^{4}$, Nory Omayra Dávalos-Rodríguez², Jorge Román Corona-Rivera ${ }^{5}$ and José Sánchez-Corona ${ }^{6}$

${ }^{1}$ Universidad de la Sierra Sur, Institute of Public Health Research, Oaxaca State Universities System, Miahuatlán de Porfirio Díaz, Oax.; ${ }^{2}$ Instituto de Genética Humana Dr. Enrique Corona Rivera, Department of Molecular Biology and Genomics, University Center of Health Sciences, Benemérita Universidad de Guadalajara; ${ }^{3}$ Trauma and Orthopedics, Hospital Ángeles del Carmen; ${ }^{4}$ Division of Genetics, Centro de Investigación Biomédica de Occidente, Instituto Mexicano del Seguro Social; ${ }^{5}$ Department of Pediatrics, Nuevo Hospital Civil Dr. Juan I. Menchaca; ${ }^{6}$ Molecular Medicine, Centro de Investigación Biomédica de Occidente, Instituto Mexicano del Seguro Social. Guadalajara, Jal. México
\end{abstract}

\begin{abstract}
Background: Achondrogenesis is a skeletal dysplasia characterized primarily by short stature, severe micromelia, short and narrow chest, prematurity, polyhydramnios, fetal hydrops, and in utero or neonatal death. Based on the radiological and histopathological findings, there are three types of achondrogenesis: type 1A (Houston-Harris), type 1B (Fraccaro) and type 2 (Langer-Saldino). Clinical case: $A$ premature female product was studied whose clinical, radiological and histopathological characteristics were compatible with achondrogenesis Type 1A. The family information allowed us to conclude that the 4 products of the 6 previous pregnancies were affected. Statistical analysis in at least 4 families previously described, including this family case showed significant differences between expected and observed number of members, being incongruent with an autosomal recessive mode of inheritance previously reported. Conclusions: therefore, it could be considered a new subtype of achondrogenesis type $1 \mathrm{~A}$ due to the presence of a preferential germline mutation.
\end{abstract}

KEY WORDS: Achondrogenesis type 1A. Germinal mutation. Skeletal dysplasia.

\section{Resumen}

Introducción: La acondrogénesis es una displasia esquelética que se caracteriza principalmente por talla baja, micromelia grave, tórax corto y estrecho, prematurez, polihidramnios, hidropesía fetal y muerte fetal in utero o neonatal. Según los hallazgos radiológicos e histopatológicos existen tres tipos de acondrogénesis: tipo 1A (Houston-Harris), tipo 1B (Fraccaro) y tipo 2 (Langer-Saldino). Caso clínico: Se sometió a estudio a un producto femenino prematuro cuyas características clínicas, radiológicas e histopatológicas fueron compatibles con acondrogénesis tipo 1A. La información familiar permitió concluir que los cuatro productos de los seis embarazos previos se encontraban afectados. El análisis estadístico en por lo menos cuatro familias previamente descritas, incluyendo este caso familiar, mostró diferencias significativas entre el número de miembros esperado y el observado, siendo incongruente con el modo de herencia autosómico recesivo previamente reportado. Conclusiones: Podría considerarse un nuevo subtipo de acondrogénesis tipo $1 A$ debida a la presencia de una mutación germinal preferencial.

PALABRAS CLAVE: Acondrogénesis tipo 1A. Mutación germinal. Displasia esquelética.

\author{
Correspondence: \\ *Diana García-Cruz \\ Sierra Mojada 950, edificio P, Segundo nivel \\ Col. Independencia \\ C.P. 44340 Guadalajara, Jal., México \\ E-mail: Dianagarcr@hotmail.com
}

Date of reception: 19-12-2017

Date of acceptance: 14-02-2018

DOI: 10.24875/CIRUE.M18000013
Cir Cir. 2018;86:81-89

Contents available at PubMed www.cirugiaycirujanos.com 


\section{Introduction}

Skeletal dysplasias are a heterogeneous group of disorders with abnormal development of the skeleton (in size and shape of the limbs, trunk and skull). Those resulting from problems in ossification normal process have been designated as osteochondrodysplasia ${ }^{1,2}$. In this group, achondrogenesis (ACG) are found, which are identifiable during fetal life or at birth, and are accompanied by polyhydramnios, fetal hydrops and pulmonary hypoplasia, which cause neonatal mortality or stillbirth $^{3}$. Patients with these dysplasias have a short neck and trunk, narrow chest, prominent abdomen, short height, severe micromelia and facial dysmorphism (exophthalmia, flat nasal bridge, short nose with anteverted nostrils, low set ears and lingual protrusion). Main radiological findings include virtual ossification absence of the cranial vault bones and vertebral bodies of sacrum, and short ribs with horizontal orientation. The ilium is shortened, in the shape of a half moon. Long bones are small, arched and occasionally stellate, with longitudinally oriented metaphyseal spurs ${ }^{3,4}$.

Thus far, three types of ACG have been described: type IA (ACG1A, Houston-Harris, MIM \# 200600), caused by mutation of the TRIP11 gene at locus 14q32; type IB (ACG1B, Fraccaro; MIM \# 600972), caused by a mutation of the SLC26A2 gene at locus $5 q 32$ (both types are described with autosomal recessive inheritance mode); and type II (ACG2, Langer-Saldino; MIM \# 200610), due to mutation of the COL2A1 gene at locus 12q13.11, with an autosomal dominant pattern. ACG has a global frequency of $1-50,000$. In the case of ACG1A, mutations in the TRIP11 gene have been reported, but without being conclusive as a single cause $^{3-8}$. These three variants are lethal in utero. Radiological and histopathological characteristics enable differential diagnosis; between types I and II it is easier, since they are clinically different ${ }^{3-6}$. The present work aims to be the first report of a new ACG1A subtype with a previously unreported mode of inheritance, which is not autosomal recessive, as well as some not previously observed histopathological findings.

\section{Clinical case}

Female newborn resulting from a seventh pregnancy. Parents were not consanguineous (Fig. 1). Since week 12 of gestation, abdominal ultrasound revealed short limbs. Since week 28, there was fetal hypoactivity, with probable dropsy and severe polyhydramnios.
Delivery occurred at 30 weeks by cesarean section. At birth, she had a body weight of $1600 \mathrm{~g}$, crown-heel length of $23 \mathrm{~cm}$, head circumference of $22 \mathrm{~cm}$, chest perimeter of $18.5 \mathrm{~cm}$, abdominal perimeter of $21 \mathrm{~cm}$ and a lower segment of $6 \mathrm{~cm}$. There were also findings consistent with rhizomelic and mesomelic dwarfism, macrocrania, mild orbital hypertelorism, auricular pavilions low implantation, short nasal bridge, short and wide nose, microretrognathia, short neck, thoracolumbar dorsal hypertrichosis, significant shortening of the trunk with costal hypoplasia, prominent abdomen and micromelia of the four limbs. The patient died 15 minutes after birth.

\section{Family and genetic study}

Parents were healthy, 35 years (father) and 33 years (mother) of age at birth of the case. Karyotype of the parents was obtained with GTG banding, which was normal in both. Genealogical analysis revealed the presence of other affected siblings, with the same clinical characteristics II-1, II-2, II-3, II-5 and II-7; II-4 was a miscarriage; II-6 was clinically and radiologicaIly healthy (Fig. 1). Family member's clinical characteristics are shown in Table 1.

\section{Imaging studies}

Full skeletal survey radiological findings are shown in table 2 and figure 2 B. Overall, axial and appendicular skeleton bones poor ossification is observed, with predominance in vertebral bodies, as well as pelvic bones hypoplasia and shortening of all four limbs long bones, with stooping thereof.

\section{Anatomopathological study}

Macroscopic description reported extensive maceration, and generalized ascites and edema (Fig. 2). Histopathological study of the femoral epiphysis by biopsy was carried out using formic acid and paraffin embedding; macroscopically, it revealed decalcified bone. Different 7-mm-thick histological sections were stained with hematoxylin/eosin, Alcian blue/PAS and Masson's trichrome, and analyzed by light microscopy. The results were: normal cartilaginous matrix, with sparse, densely packed and vacuolated, PAS-positive chondrocytes, some of them with an aspect of bullseye (at the center of the biopsy with Alcian blue/PAS; Fig. 3); elongated bone lacunae and a pseudo-mesenchymal zone 

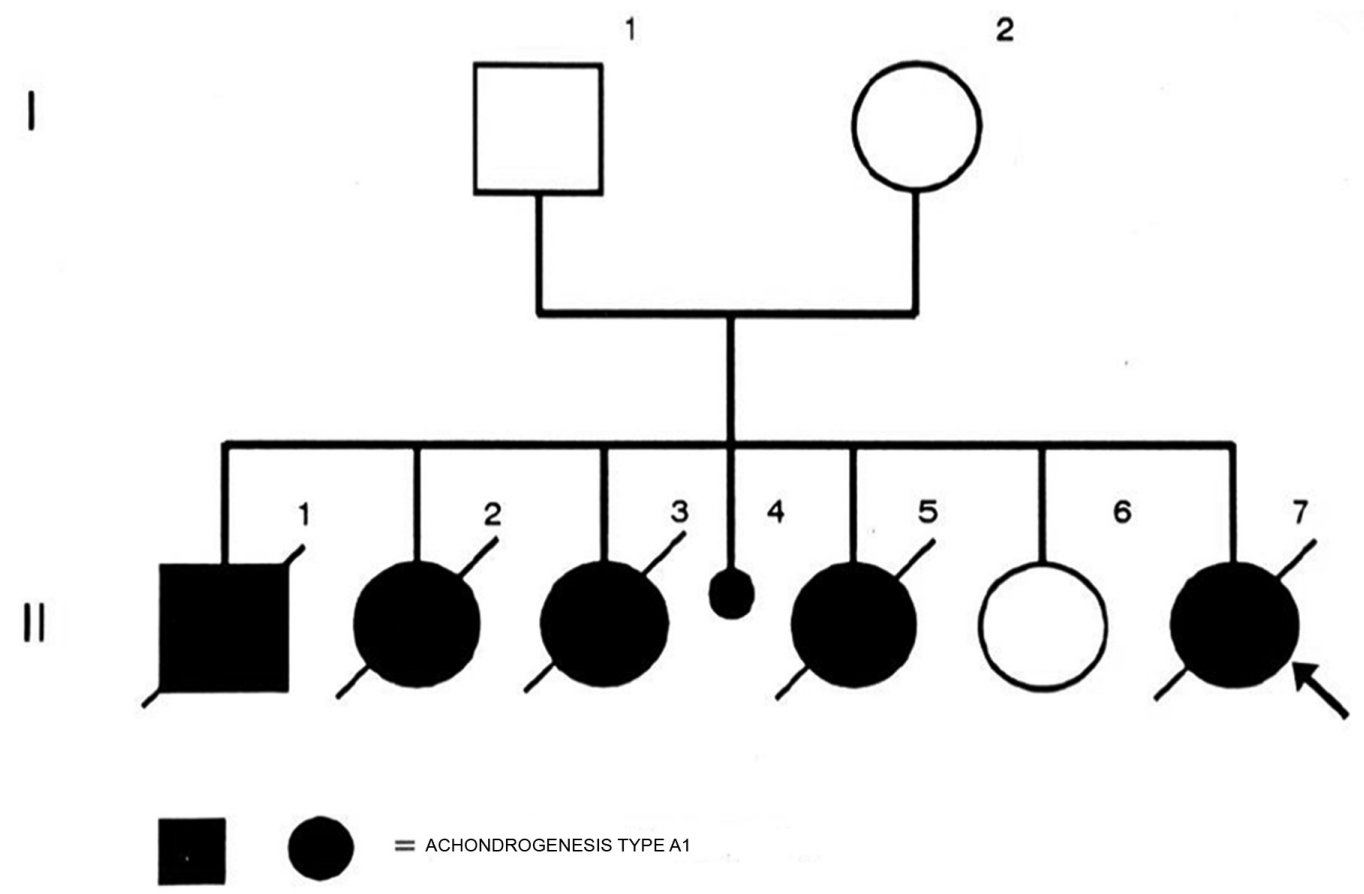

Figure 1. Family tree.

Table 1. Proposita siblings clinical data

\begin{tabular}{|c|c|c|c|c|c|c|}
\hline Gestation & II-1 & II-2 & II-3 & II-4 & II-5 & II-6 \\
\hline Gender & Male & Female & Female & Not determined & Female & Female \\
\hline $\begin{array}{l}\text { Gestational age in } \\
\text { weeks }\end{array}$ & 29 & $23 / 24$ & 28 & 8 & 30 & 39 \\
\hline Clinical findings & Short limbs & $\begin{array}{l}\text { Multiple } \\
\text { malformations }\end{array}$ & $\begin{array}{l}\text { Cleft lip, short and flat } \\
\text { nose, short neck, trunk } \\
\text { and limbs, hydrops } \\
\text { fetalis }\end{array}$ & $\begin{array}{l}\text { Does not apply, it } \\
\text { was a miscarriage }\end{array}$ & $\begin{array}{l}\text { Cleft lip, short and flat } \\
\text { nose, short neck, trunk } \\
\text { and limbs, hydrops } \\
\text { fetalis }\end{array}$ & Normal \\
\hline $\begin{array}{l}\text { Death age/ } \\
\text { continued hours }\end{array}$ & 4 & 2 & 2 & Does not apply & 2 & Does not apply \\
\hline Birth height (cm) & Not recalled & Not recalled & Not recalled & Does not apply & 23 & 50 \\
\hline Birth weight (g) & Not recalled & 400 & Not recalled & Does not apply & 650 & 3000 \\
\hline Polyhydramnios & Data unknown & Data unknown & Present & Absent & Present & Absent \\
\hline Placenta & Data unknown & Degeneration & Data unknown & Data unknown & $\begin{array}{l}\text { Edematized and } \\
\text { hypochromic }\end{array}$ & Normal \\
\hline
\end{tabular}

between cartilage and bone. No intrachondrocytic inclusion bodies were found, and extraskeletal cartilage was found to be involved.

\section{Discussion}

Pathognomonic data consistent with ACG1A were found in the proposita, as well as in several members of the family, including polyhydramnios in the second trimester of gestation and radiological abnormalities (multiple dysostosis) (Table 1) 13,6,-13. Most cases are premature and stillbirths; some remain alive for minutes after birth, as in the present case ${ }^{7}$. Information of the analyzed genealogy allowed concluding that four products of the six previous pregnancies were clinicaIly affected with ACG1A. The proposita was more affected (she had serious facial dysmorphism) in comparison with her brother, who died with the same problem; this is due to hydrops fetalis and polyhydramnios, which are the cause of malformations. 
Table 2. Comparative clinical and imaging data in achondrogenesis and the propositia

\begin{tabular}{|c|c|c|c|}
\hline Clinical characteristics & Type IA* & Type IB ${ }^{\dagger}$ & Proposita \\
\hline Polyhydramnios & $18 / 22$ & $5 / 24$ & + \\
\hline \multicolumn{4}{|l|}{ Gestational age } \\
\hline Full term & $1 / 22$ & $4 / 25$ & \\
\hline Prematurity & 20/22 & $16 / 25$ & + \\
\hline \multicolumn{4}{|l|}{ Death age } \\
\hline Stillborn & $15 / 22$ & $11 / 25$ & \\
\hline Minutes & $11 / 22$ & $13 / 25$ & + \\
\hline Birth length (cm) & $22-30$ & $23.5-30$ & 23 \\
\hline Birth weight (g) & $520-1840$ & $1020-2200$ & 1600 \\
\hline Gender ratio (male/female) & $15: 7$ & $5: 13$ & Female \\
\hline Consanguinity & 3 & 2 & - \\
\hline Member of a family with multiple affected siblings & 9 & $5^{\ddagger}$ & + \\
\hline \multicolumn{4}{|l|}{ Radiologic findings } \\
\hline Poorly ossified skull & + & + & + \\
\hline Rib fractures & + & - & - \\
\hline Non-ossified vertebrae & + & - & + \\
\hline Ossified posterior pedicles & - & + & - \\
\hline llium & Arched & Crenated & Arched \\
\hline Unossified ischium & - & + & - \\
\hline Femur & $\begin{array}{c}\text { Wedge-shaped, with metaphyseal } \\
\text { spikes }\end{array}$ & Trapezoid & $\begin{array}{c}\text { Wedge-shaped, with metaphyseal } \\
\text { spikes }\end{array}$ \\
\hline Tibia & Shortened, with metaphyseal flare & Stellate & Shortened, with metaphyseal flare \\
\hline Fibula & Shortened, with metaphyseal flare & Unossified & Shortened, with metaphyseal flare \\
\hline
\end{tabular}

ACG1A differential diagnosis is established by ruling out conditions of two nosological groups of diseases with high perinatal mortality: chromosomal defects that produce facial dysmorphism and malformations, which were ruled out, since cytogenetic evaluation in both parents was normal; and skeletal lethal dysplasias, including diastrophic dysplasia MIM \# 222600 (caused by mutations in the SLC26A2 gene, at locus $5 q 32)$, short rib thoracic syndromes with or without polydactyly (there are several types with autosomal dominant or recessive inheritance patterns), osteogenesis imperfecta type II, MIM \# 166210, with autosomal dominant pattern, caused by mutations in the COL1A2 gene, at locus $7 q 21.3$, and by the COL1A1 gene at locus 17q21.33, "baby rattle" pelvic dysplasia, MIM \# 605838 (still without a candidate gene), fibrochondrogenesis type 1, MIM \# 228520 (with an autosomal recessive pattern caused by mutations in COL11A1 locus 1p21.1), and type 2, MIM \# 614524 (with both autosomal dominant and recessive inheritance, caused by mutations in COL11A2, locus 6p21.32), thanatophoric dysplasia MIM \# 187600 (caused by mutations in the FGFR3 gene at locus 4p16.3), and especially ACG2, due to the autosomal dominant transmission pattern, similar to that found in the analyzed family-13.

The diagnosis can also be established by sequencing. For patients with ACG2, mutations are found in COL2A16,10; in ACG1B, in the DTDST gene ${ }^{3,5,9,12-17}$. In the search for an implicated gene for ACG1A, Smits et al..$^{13}$ found that mice with GMAP-210 deficiency died with a phenotype similar to ACG1A. This gene is 

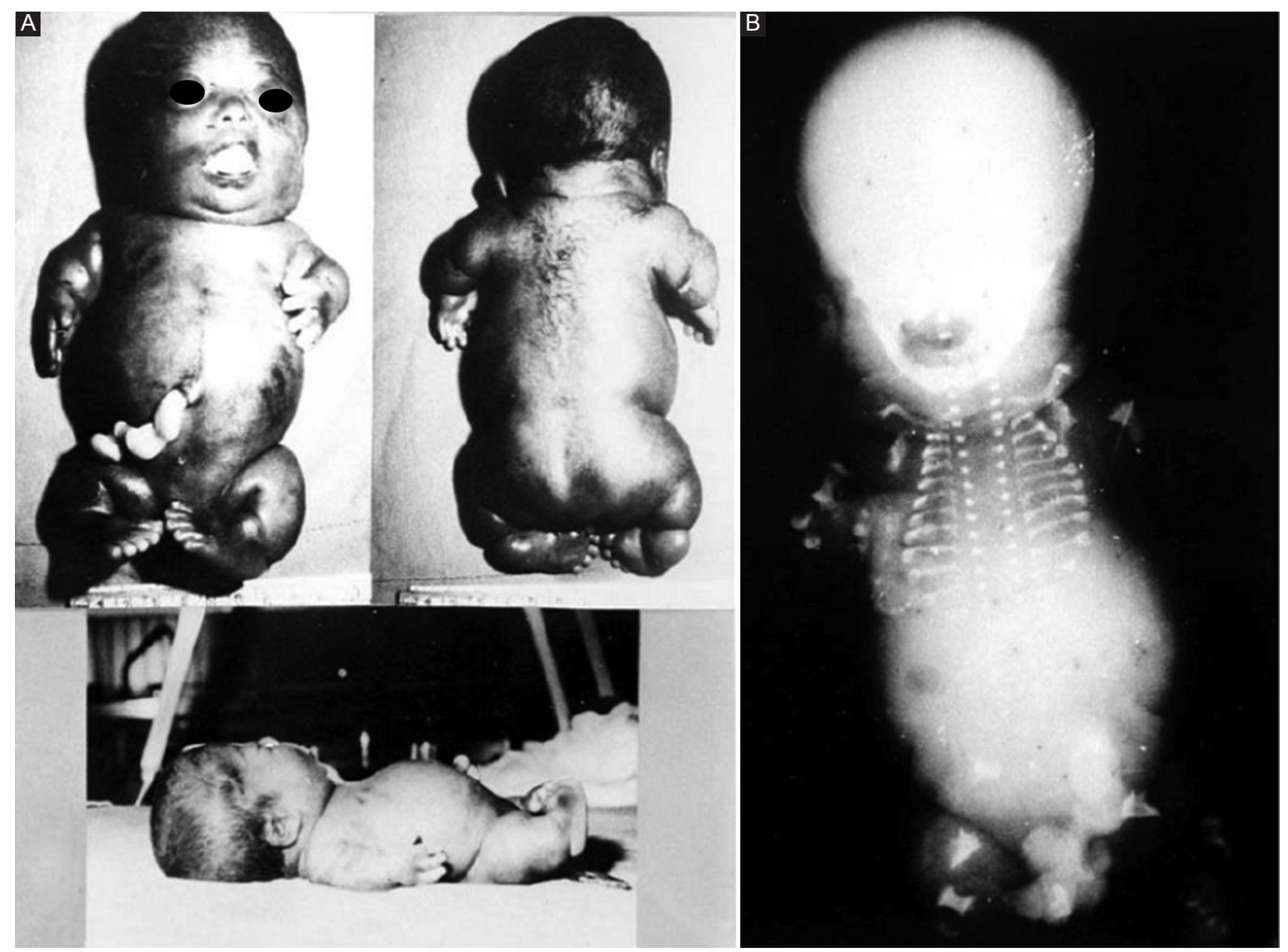

Figure 2. A: post-mortem photograph of the patient. Notice the hydropic appearance and the neck, chest and short limbs. B: photograph of patient $X$-rays. Notice the poor ossification of the skull and vertebrae, short ribs, hypoplastic pelvis, arched ilium and wedge-shaped femur.

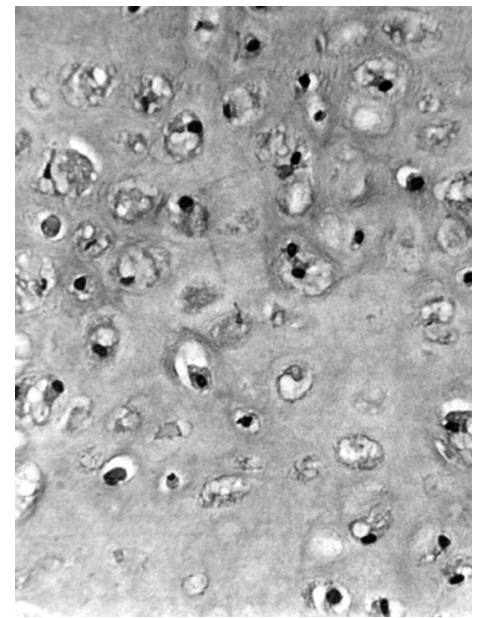

Figure 3. Femur biopsy. Notice the vacuolated chondrocytes.

homologous to TRP11 in humans, where 11 mutations have been found (most of them in the compound heterozygous state) ${ }^{13}$. Apparently, these mutations are inherited with an autosomal recessive inheritance pattern, and since those affected are compound heterozygotes, it is speculated that they may remain alive for minutes or days after birth, since homozygotes are incompatible with life, and thus are rare, as it occurs in thanatophoric dysplasia ${ }^{14-16}$. Grigelioniene et al. ${ }^{4}$ also show evidence on the autosomal recessive pattern and in contrast they found dizygotic twins with an ACG1A clinical and radiological phenotype with a homozygous genotype for a new nonsense mutation in TRIP114. They also found a patient who was compound heterozygous for a nonsense mutation and a deletion of the 3 ' end of the gene, with milder manifestations. Therefore, mutations of the TRIP11 gene may encompass a wider phenotypic range, but to date they are not the only cause of $A C G 1 A^{13}$, as we can see in the family of the proposita analyzed in this report, since, clinically, they correspond to cases with ACG1A, but the genealogy is not consistent with an autosomal recessive inheritance pattern.

In view of the above, the frequency of expected $(E)$ and observed $(O)$ affected members was analyzed in three families with ACG1A clinical characteristics reported by Borochowitz, et al..$^{17}$ (Table 1), together with that of the present report $(n=22, E=6$ and $O=16)$. Differences were found between $E$ and $O$ affected members; $O$ cases are three times higher than $E$ 
cases $\left(X^{2}=26.68, p<0.001\right)$. If we consider that in diseases with autosomal recessive inheritance pattern there is a risk of recurrence of $25 \%$ in the siblings of an affected subject, this is not met in the proposita genealogy and neither in those three genealogies, and therefore not all ACG1A cases are explained by this inheritance pattern. Taken as a whole, these data suggest that there may be a parental de novo preferential germline mutation, whereby the patients' parents are asymptomatic carriers of a mutation in the heterozygous state, inherited by their offspring with an autosomal dominant pattern, which is supported by the present case report, since in the family there were deaths, and some affected subjects died minutes after birth, as the proposita did. In cases with this pattern, the risk of recurrence is $50 \%$ or higher (as observed in the analyzed family), and this is the value that should be used in genetic counseling for this pathology in such cases. Risk is $25 \%$ when the condition occurs in families with an autosomal recessive pattern.

Germinal mosaicism for a dominant gene might be another possibility that would explain the ACG1A pattern discussed in this work, since it has also been reported in achondroplasia (ID MIM \# 100800), pseudoachondroplasia (ID MIM \# 177170) and ACG1B, which are autosomal dominant dysplasias where cases have been reported with the same transmission pattern, as in the present family, where recurrence is associated with germinal mosaicism ${ }^{16-20}$.

Germline mutation is another explanation, since the cell continues to divide into a somatic cell before separation into germ cell lines. Considering that in the propositi's parents (mosaicism carriers) some slight histopathological alterations in the connective tissue might be observed ${ }^{18}$, Superti-Furga, et al. ${ }^{14}$ postulated that ACG1 could be classified into different subgroups. Vargas $^{21}$ also reported a rare sporadic case with ACG1A and B peculiar characteristics. A family has been reported where the parents had had undergone 3 pregnancies and did not have a single child alive; the last one, a stillborn, was a 24-week fetus with clinically-detected $A C G 1 A^{22}$. These data support the hypothesis that the present case and other ACG1A recurrent cases presumably correspond to a non-described subgroup, due to germinal mosaicism or parental de novo preferential germline mutation.

The search for a germline mutation or a mosaic, or a parental de novo germline preferential mutation in TRIP11, requires molecular analysis of different tissues of all relatives, as well as a gene expression analysis, with biopsy and immunohistochemistry ${ }^{14-21}$, which was not possible to be carried out, since affected subjects are deceased. For ethical reasons, since the mother is asymptomatic and had been able to bear a healthy child, biopsy taking was not approved, since these are also high-risk pregnancies. However, it can be part of the diagnostic workup for future ACG1A cases that exhibit an inheritance pattern such as that which is being reported. The results of these tests, when negative, open the hypothesis of another gene with dominant inheritance pattern mutations being the cause of ACG1A, either by a de novo or germline, and even mosaic mutation. Thus far, these theories cannot be ruled out, since, as in the case of diseases caused by lethal genes, it is difficult to arrive on time to take tissue samples for cytogenetic and molecular testing. As in the present case, when we were informed about the patient for evaluation, she had already died within minutes, and her siblings were already dead. For many skeletal dysplasias, molecular diagnosis is quite useful, but, in ACG, standards for their request are not well established, since the pathogenic mechanis$\mathrm{ms}$ are not entirely demonstrated ${ }^{21}$.

There are few ACG studies in the Latin American population. Few cases have been described, among them a Mexican newborn girl who arrived at 38 weeks of gestation and died of bradycardia and respiratory failure; clinical and immunohistopathological diagnosis of ACG2 (Langer-Saldino) was established ${ }^{23}$. In the Venezuelan population a 23-week female still-birth was reported, with hydrops fetalis, occipital cystic hygroma, hypertelorism, micromelia and polyhydramnios, where clinically, by imaging, cytogenetics and histopathology, ACG1B was concluded, as well as one case of a subtype with ACG and peculiar characteristics $^{21,24}$. With a very similar approach, another sporadic female-gender case was reported in the Colombian population, who was severely affected with ACG1A and whose gestation was interrupted at 23 weeks for being a high-risk pregnancy ${ }^{25}$. The present case is the first one in the Mexican population with ACG1A and the first report in the literature to present an ACG1A with an inheritance pattern that is not autosomal recessive.

From the histopathological point of view, differential diagnosis can be established (Table 3). In transgenic murine models, the ACG1A skeletal phenotype has been shown to be exclusively caused by cartilage development defects, although bone development is also abnormal because of the cartilage defect, since chondrogenesis is closely related to bone formation ${ }^{26}$. 
Table 3. Achondrogenesis types morphopathological comparison

\begin{tabular}{|c|c|c|c|}
\hline Achondrogenesis variants & $\begin{array}{l}\text { Histopathological findings reported in } \\
\text { achondrogenesis }\end{array}$ & $\begin{array}{l}\text { Pathognomonic histopathological } \\
\text { changes }\end{array}$ & Ref. \\
\hline $\begin{array}{l}\text { ACG1A, Houston-Harris/ } \\
\text { highly lethal, rare } \\
\text { achrondoplasia }\end{array}$ & $\begin{array}{l}\text { Densely packed chondrocytes with bullseye } \\
\text { appearance, large round or oval inclusions, PAS-positive, } \\
\text { with vacuoles attached to the cell membrane found } \\
\text { within } \\
\text { Normal monochromatic cartilaginous matrix, with } \\
\text { moderate perivascular fibrosis and disorganized growth } \\
\text { plates with hypertrophic chondrocytes, extending to the } \\
\text { primary and secondary trabeculae } \\
\text { Chondrocytes show histomorphic signs of protein } \\
\text { material intracellular retention, reduced amount of } \\
\text { proteoglycans, with thinning of collagen fibers } \\
\text { Columnar chondrocyte zones with poor organization in } \\
\text { growth plates } \\
\text { On electron microscopy, dilated endoplasmic reticulum } \\
\text { and Golgi apparatus can be appreciated. Golgi } \\
\text { apparatus cisternae expansion is also observed } \\
\text { By immunohistochemistry, normal pattern of collagens, } \\
\text { aggrecan, matrilins, oligomeric cartilage protein and } \\
\text { type } 10 \text { collagen (COL10A1) reduced expression have } \\
\text { been reported }\end{array}$ & $\begin{array}{l}\text { Abnormal metaphysis } \\
\text { PAS-positive chondrocytes with } \\
\text { cytoplasmic inclusions } \\
\text { Hypertrophic chondrocytes resemble } \\
\text { bullseyes }\end{array}$ & $\begin{array}{c}20-23 \\
29\end{array}$ \\
\hline ACG1B, Fraccaro & $\begin{array}{l}\text { Chondrocyte disorganization, which show an increase in } \\
\text { size and number (hypercellularity) } \\
\text { Marked cartilaginous matrix loss and irregularity in the } \\
\text { endochondral ossification columnar line, multifocal } \\
\text { sclerosis and matrix calcification } \\
\text { Perichondrocytic collagen rings }\end{array}$ & $\begin{array}{l}\text { Abnormal metaphysis } \\
\text { Perichondrocytic collagen rings }\end{array}$ & 19,29 \\
\hline $\begin{array}{l}\text { ACG2, Langer-Saldino/lethal } \\
\text { achondrogenesis }\end{array}$ & $\begin{array}{l}\text { Significant ossification loss and irregular ossification in } \\
\text { different bones } \\
\text { Chondro/osseous tissue shows high cell density and } \\
\text { reduced extracellular matrix } \\
\text { Metaphyses show disorganized endochondral } \\
\text { ossification with balloon-shaped chondrocytes; } \\
\text { periosteum with advanced ossification, chondroid matrix } \\
\text { and elongated chondrocyte lacunae } \\
\text { Chondrocytes are increased in number and size, growth } \\
\text { zone columns are irregularly arranged } \\
\text { Osteoid deposit without calcification, chondroid matrix } \\
\text { exhibits vascular channels and cartilage hypervascularity } \\
\text { Primary trabeculae are thin and irregular, and } \\
\text { perivascular fibrosis } \\
\text { No inclusions in chondrocytes } \\
\text { Irregular vascular penetration in ossification line } \\
\text { Immunohistochemistry for apoptosis: BAK } 80 \% \text {, } \\
\text { BAX } 80 \% \text { and Bcl-X } 10 \% \\
\text { Immunohistochemistry for cell proliferation: focally } \\
\text { positive PCNA (cell proliferation antigen) }\end{array}$ & $\begin{array}{l}\text { Abnormal metaphysis } \\
\text { Chondrocytes are balloon-shaped } \\
\text { Markedly enlarged chondrocyte lacunae }\end{array}$ & 18,29 \\
\hline
\end{tabular}

This explains why in the femoral biopsy of the of the ACG1A index case, elongated bone lacunae and a pseudomesenchymal zone were found between the cartilage and bone tissue, as well as extraskeletal cartilage involvement. These findings have not been previously reported. Cartilage and bone have also been reported to be highly secretory tissues, with high traffic of molecules through the membranes, which affects the traffic of a subset of proteins expressed in chondrocytes and leads to a membrane traffic that harms globally. Affected molecules include sulfated glycosaminoglycans ${ }^{26}$ (which are part of chondrocytes extracellular matrix and capsule). This explains why the index case biopsy shows that the chondrocyte capsule is thinner (Fig. 3).

In biopsies of ACG1A cases, through immunohistochemistry, the matrix molecules have been also reported to have a normal distribution pattern, except for type $X$ collagen, which results in alteration of the assembly of the cartilaginous matrix with sulfated 
glycosaminoglycans ${ }^{27}$. Presumably, the consequences of this event are the processes of maturation and differentiation of chondrocytes and endochondral bone formation, which are severely affected ${ }^{27}$. Presence of inclusion bodies, hypertrophic vacuolated chondrocytes and disorganized chondrocyte plaques has also been described ${ }^{25-29}$; all these findings are similar to those observed in the proposita's biopsy, except that inclusion bodies were not observed, a finding that has not been previously described. The absence of inclusion bodies can be explained by the reduced amount of intracellular collagen and proteoglycans, which is conclusive of the severe endochondral formation disorder. Considering all these histopathological findings, the COL10A1 gene (which encodes collagen 10) could be proposed as the possible gene involved in ACG1A with non-recessive or recurrent pattern, as in the family analyzed in the present case, which is supported if we consider that mutations in COL10A1 are transmitted with a dominant pattern (inheritance where germline or mosaic mutation, or preferential de novo parental germline mutation cases fit) and produce metaphyseal chondrodysplasia, Schimd type. ${ }^{30}$ In this sense, recurrent non-recessive ACG1A might be an allelic variant of the COL10A1 gene, a very similar case to achondroplasia (produced by mutations in the FGFR gene) and thanatophoric dwarfism, which is an allelic variant of the same gene. In this work, it was not possible to continue with TRIP11 and COL10A molecular study or histopathological analysis, due to the non-bioavailability of tissues. Masson's trichrome stain was applied to different sections of the index case femur, which allowed us to scan the structure of the cartilaginous matrix collagen fibers in general, which did not show alterations, but, with this stain, type-10 collagen cannot be particularly explored, which is a limitation of this work.

\section{Conclusions}

By means of clinical, imaging and pathology examination, the first report of a new ACG1 subgroup that corresponds to ACG1A, but with an alternative inheritance pattern is presented. Certainly, autosomal recessive inheritance has been reported in ACG1A, but it was ruled out in the present report. In future ACG1A cases with this alternative inheritance pattern, or in recurrent cases, it shall be convenient to search for mutations in the COL10A1 gene by means of exome sequencing. This way, this is the first work in the Mexican population with ACG1A and the first one in the literature to present an ACG1A with an inheritance pattern that is not of the autosomal recessive type. Concluding whether it corresponds to an exclusively germline defect or rather to somatic/germinal mosaicism in TRIP11 and COL10A, or in some other gene was not possible, given that availability of several tissues of the family is required (of those affected, both deceased and healthy asymptomatic subjects) in order to make the detection of mutations, as well as to carry out gene expression analysis, which was limited by hospital ethical issues related to patient benefit.

\section{Acknowledgements}

To MSc Rogelio Troyo-Sanromán, for his support in statistical analysis. To Dr. Lina S. Correa-Cerro for the kindness she had in reading the manuscript and expressing some opinions

\section{Ethical responsibilities}

Protection of people. The authors declare that the followed procedures were in agreement with the responsible human experimentation committee ethical standards and in accordance with the World Medical Association and the Declaration of Helsinki.

Confidentiality of data. The authors declare to have followed the protocols of their work center on the publication of patient data.

Right to privacy and informed consent. The authors have obtained informed consent from the patients and/or subjects referred to in the article. This document is in possession of the corresponding author.

\section{Funding}

There was no funding by any institution. The patient's parents and the work group financed the studies that were carried out.

\section{Conflict of interests}

None of the authors has any conflicts of interests.

\section{References}

1. Unger S, Lachman RS, Rimoin DI. Chondrodysplasias. En: Rimoin D, Pyeritz R, Korf B, editores. Emery and Rimoin's Principles and practice of medical genetics. $5^{\text {th }}$ ed. Edinburgh: Churchill Livingstone Elsevier; 2006. p. 3709.

2. Horton WA. Abnomalities of bone estructure. En: Rimoin D, Pyeritz R, Korf B, editores. Emery and Rimoin's Principles and practice of medical genetics. $5^{\text {th }}$ ed. Edinburgh: Churchill Livingstone Elsevier; 2006. p. 3754. 
3. Batge B, Nerlich A, Brenner R, Yang C, Müller PK. Collagen type II in Langer Saldino achondrogenesis: absence of major abnormalities in a less severe case. Acta Paediatr. 1992;81:158-62.

4. Grigelioniene G, Geiberger S, Papadogiannakis N, Makitie O, Nishimura G, Nordgren $\mathrm{A}$, et al. The phenotype range of achondrogenesis $1 \mathrm{~A}$. Am J Med Genet Part A. 2013;161A:2554-8.

5. Kapur RP. Achondrogenesis. Pediatr Dev Pathol. 2007;10:253-5.

6. OMIM. Online Mendelian Inheritance in Man, OMIM (TM). McKusick-Nathans Institute for Genetic Medicine, Johns Hopkins University (Baltimore, MD) and National Center for Biochnology Information, National Library of Medicine (Bethesda, MD). 2016. (Consultado el 10 de noviembre de 2017.) Disponible en: https://www.omim.org

7. Chen CP, Liu FF, Jan SW, Lin YN, Lan CC. A case of achondrogenesis type 1 A with an occipital encephalocele. Genet Couns. 1996;7:193-9.

8. Hastbacka J, de la Chapelle A, Mahtani MM, Clines G, Reeve-Daly MP, Daly M, et al. The diastrophic dysplasia gene encodes a novel sulfate transporter positional cloning by fine-structure linkage disequilibrium mapping. Cell. 1994;78:1073-87.

9. Ornoy A, Sekeles E, Smith P, Simkin A, Kohn G. Achondrogenesis type I in three sibling fetuses. Scanning and transmission electron microscopic studies. Am J Pathol. 1976;82:71-84

10. Korkko J, Cohn DH, Ala-Kokko L, Krakow D, Prockop DJ. Widely distributed mutations in the COL2A1 gene produce achondrogenesis type II/ hypochondrogenesis. Am J Med Genet. 2000;92:95-100.

11. Cormier-Daire V, Savarirayan R, Lachman RS, Neidich JA, Grace K, Rimoin DL, et al. "Baby rattle" pelvis dysplasia. Am J Med Genet. 2001; 100:37-42.

12. Rossi A, Superti-Furga A. Mutations in the diastrophic dysplasia sulfate transporter (DTDST) gene (SLC26A2): 22 novel mutations, mutation review, associated skeletal phenotypes, and diagnostic relevance. Hum Mutant. 2001;17:159-71.

13. Smits P, Bolton AD, Funari V, Hong M, Boyden ED, Lu L, et al. Lethal skeletal dysplasia in mice and humans lacking the golgin GMAP-210. N Engl J Med. 2010;362:206-16.

14. Superti-Furga A, Hastbacka J, Rossi A, van der Harten JJ, Wilcox WR, Cohn $\mathrm{DH}$, et al. A family of chondrodysplasias caused by mutations in the diastrophic dysplasia sulfate transporter gene and associated with impaired sulfation of proteoglycans. Ann N Y Acad Sci. 1996;785:195-201.

15. Karniski LP. Functional expression and cellular distribution of diastrophic dysplasia sulfate transporter (DTDST) gene mutations in HEK cells. Hum Mol Genet. 2004;13:2165-71.

16. Feshchenko SP, Krasnopol'skaia KD, Rebrin IA, Rudakov SS. Molecular heterogeneity of proteoglycan aggregates of human hyalin cartilage in normal conditions and in systemic bone dysplasia. Vopr Med Khim. 1989;35:24-33.

17. Borochowitz Z, Lachman R, Adomian G, Spear G, Jones K, Rimoin DL. Achondrogenesis type I: delineation of further heterogeneity and identification of two distinct subgroups. J Pediatr. 1988;112:23-31.

18. Zlotogora J. Germ line mosaicism. Hum Genet. 1998;102:381-6.

19. Comstock JM, Putnam AR, Sangle N, Lowichik A, Rose NC, Opitz JM. Recurrent of achondrogenesis type 2 in sibs: additional evidence for germinale mosaicism. Am J Med Genet Part A. 2010;152A:1822-4.

20. Freisinger $P$, Stanescu J, Jacob B, Cohen-Solal L, Maroteaux P, Bonaventure $\mathrm{J}$. Achondrogenesis type IB (Fraccaro): study of collagen in the tissue and in chondrocytes cultured in agarose. Am J Med Genet. 1994;49:439-46.

21. Vargas AJ. Valoración genética de las displasias esqueléticas. Valencia, Venezuela: Universidad de Carabobo; 1994. p. 433.

22. Oztas S, Dogan H, Kadanli S, Tatar AG. Achondrogenesis type $1 A$ (Houston-Harris). A case diagnosed at prenatal period. Gazi Medical J. 2002;13:149-51.

23. De Anda PA, Durán-Padilla MA. Acondrogénesis tipo II (Langer-Saldino). Estudio morfológico e inmunohistoquímico. Rev Med Hosp Gin Mex. 2005;68:86-9.

24. León de Pérez M, Velazco J, Estrada-Corona P, Puerta-Rodríguez $\mathrm{H}$, Pérez-León J, Pérez- León, et al. Hallazgos ecosonográficos, citogenéticos y anatomopatológicos en feto con acondrogénesis tipo 1B. Boletín Médico de Postgrado. 2005;21(2).

25. Acosta-Guio JC, Olaya M, Zarante MI. Acondrogénesis tipo IA: reporte de caso. Rev Colom Radiol. 2011;22:3189-92.

26. Bird IM, Kim SH, Schweppe DK, Caetano-Lopes J, Robling AG, Charles JF, et al. The skeletal phenotype of achondrogenesis type $1 \mathrm{~A}$ is caused exclusively by cartilage defects. Development. 2018 Jan 8;145(1). pii: dev156588.

27. Aiger T, Rac T, Niederhagen M, Zaucke F, Schmitz M, Pöhls U, et al. Achondrogenesis type 1A (Houston-Harris): a still-unresolved molecular phenotype. Pediatr Dev Pathol. 2007;10:328-34.

28. Roseberg AE, Krishnastty NG. Skeletal system. En: Gilbert-Barnes E, editor. Potters's Pathology of the fetus, infant and child. $2^{\text {nd }}$ ed. Maryland: Mosby/Elsevier; 2007. p. 1797-897.

29. Parwanto MLE. The genetic aspect and morphological appearance of achondrogenesis. Int J Reprod Contracept Obstet Gynecol. 2017;6: 3203-12.

30. Warman ML, Abbott M, Apte S, Hefferon T, Mclntosh I, Cohn D, et al. A type $\mathrm{X}$ collagen mutation causes Schmid metaphyseal chondrodysplasia. Nature Genet. 1993;5:9-82. 